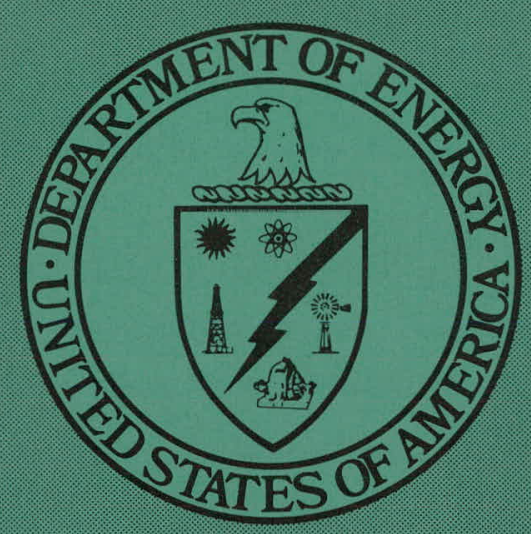

BERC/RI-77/17

CHARACTERIZATION OF HYDROTREATED TOSCO SHALE OIL

By

J. W. Vogh, S. A. Holmes, G. P. Sturm, Jr.,

P. W. Woodward, and J. E. Dooley

Dato Publiched-Docember 1977

Bartlesville Energy Research Center

Energy Research and Development Administration

Bartlesville, Oklahnma

TECHNICAL INFORMATION CENTER

UNITED STATES DEPARTMENT OF ENERGY

DISTRBBution of THIS 


\section{DISCLAIMER}

This report was prepared as an account of work sponsored by an agency of the United States Government. Neither the United States Government nor any agency Thereof, nor any of their employees, makes any warranty, express or implied, or assumes any legal liability or responsibility for the accuracy, completeness, or usefulness of any information, apparatus, product, or process disclosed, or represents that its use would not infringe privately owned rights. Reference herein to any specific commercial product, process, or service by trade name, trademark, manufacturer, or otherwise does not necessarily constitute or imply its endorsement, recommendation, or favoring by the United States Government or any agency thereof. The views and opinions of authors expressed herein do not necessarily state or reflect those of the United States Government or any agency thereof. 


\section{DISCLAIMER}

Portions of this document may be illegible in electronic image products. Images are produced from the best available original document. 


\section{NOTICE}

This report was prepared as an account of work sponsored by the United States Government. Neither the United States nor the United States Department of Energy, nor any of their employees, nor any of their contractors, subcontractors, or their employees, makes any warranty, express or implied, or assumes any legal liability or responsibility for the accuracy, completeness or usefulness of any information, apparatus, product or process disclosed, or represents that its use would not infringe privately owned rights.

This report has been reproduced directly from the best available copy.

Available from the National Technical Information Service, U.S. Department of Commerce, Springfield, Virginia 22161.

Price: Paper Copy $\$ 4.00$

Microfiche $\$ 3.00$ 


\section{CHARACTERIZATION OF HYDROTREATED TOSCO SHALE OIL}

\section{by}

J. W. Vogh, S. A. Holmes, G. P. Sturm, Jr., P. W. Woodward, and J. E. Dooley

Bartlesville Energy Research Center Bartlesville, Oklahoma
This NoTICE

sponsored prepared as an eccount of work sponsored by the United States Government. Neither the United States nor the United States Department of Energy, nor any of their employees, nor any of their contractors, subcontractors, or their employees, makes any warranty, express of implied, or assumes any lega liability or responsibility for the accuracy, completeness or usefulness of any information, apparatus, product or propea disolokid, vi" icplesellis usat lts usè would not infringe privately owned rights.

Date Published-December 1977 


\section{CONTENTS}

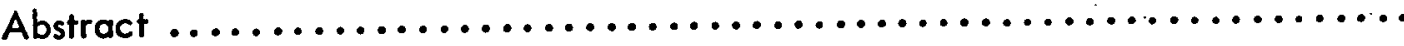

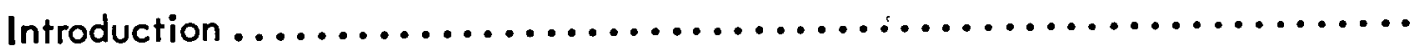

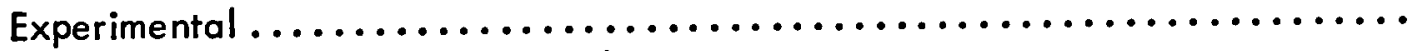

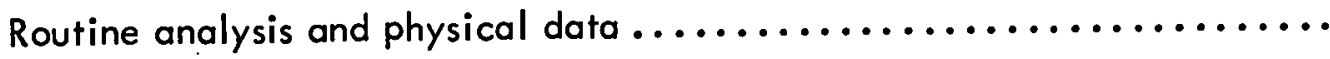

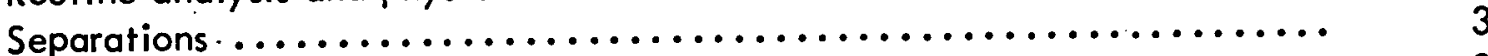

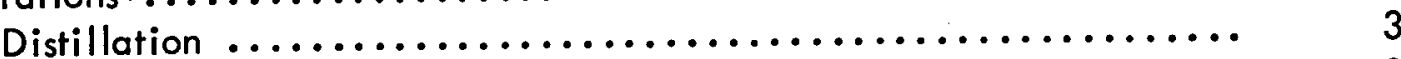

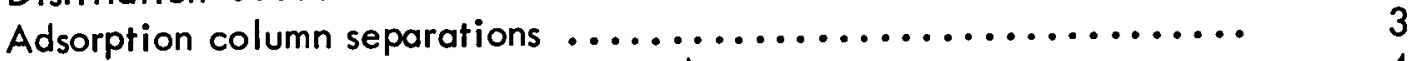

Isolation of acidic and basis compounds $, \ldots \ldots \ldots \ldots \ldots \ldots \ldots \ldots, 4$

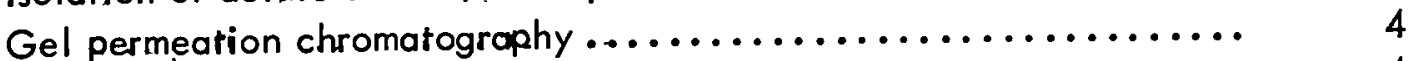

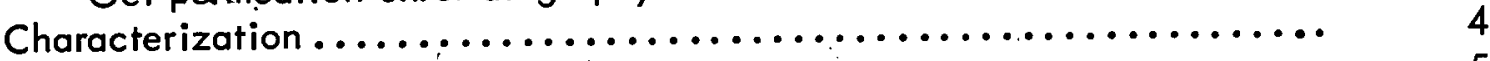

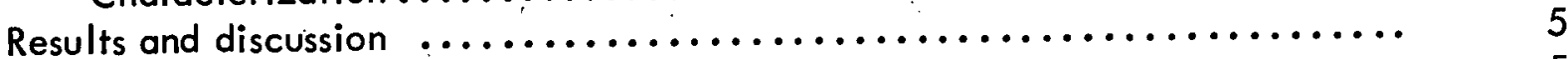

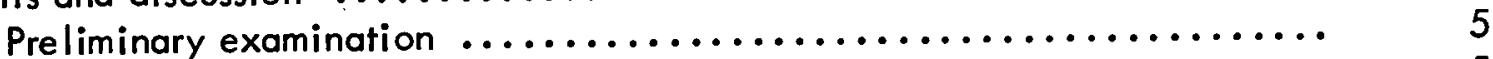

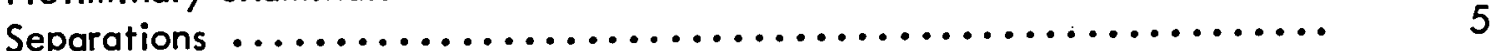

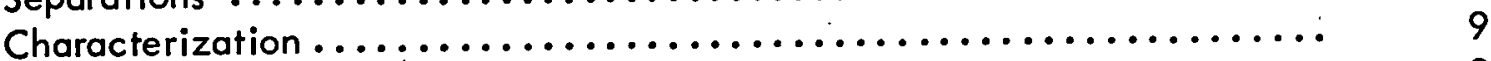

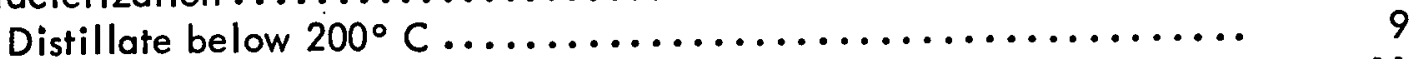

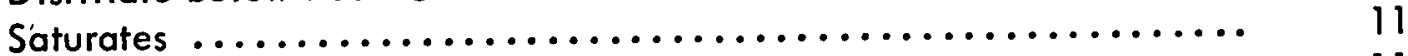

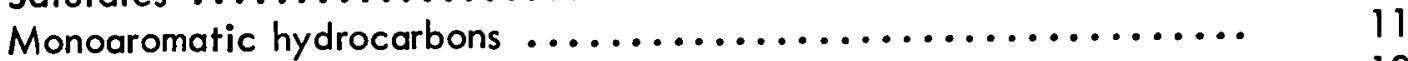

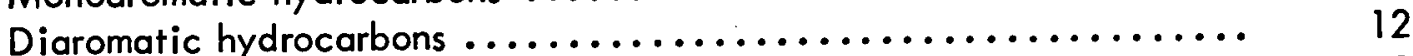

Polyaromatic-polar material ........................... 12

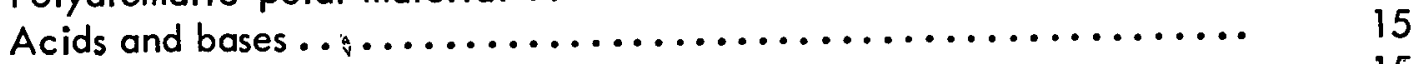

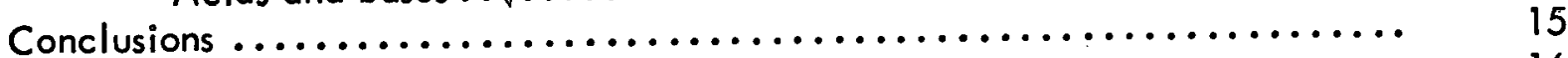

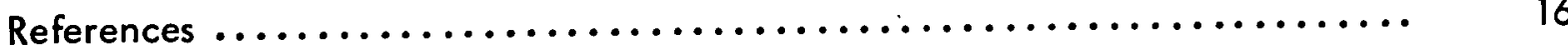

\section{ILLUSTRATIONS}

1. Gas chromatograms of indicated fractions $\ldots . . \ldots \ldots \ldots \ldots \ldots \ldots \ldots$

2. Gel permeation chromatography of aromatic concentrates .............

\section{TABLES}

1. Preliminary data of ARCO-1 hydrotreated shale oil ............... 6

2. Physical property data for distillates of ARCO-I hydrotreated

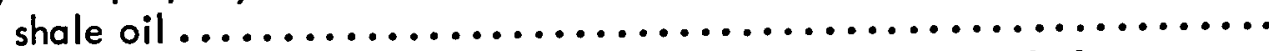

3. Weight percent yields in adsorption chromatography of ARCO-1

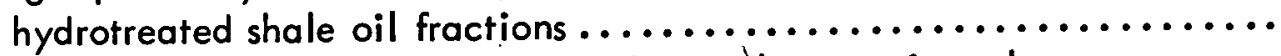

4. Acid and base concentrates obtained from polyaromatic-polar material. Weight percent of distillate fraction ................. 
TABLES-Continued

$\underline{\text { Page }}$

5. Hydrocarbon composition of distillate boiling below $200^{\circ} \mathrm{C} \ldots \ldots \ldots \ldots$ 9...

6. Ring number distribution of saturate concentrates. ARCO-1

hydrotreated shale oil.

7. Ring number distribution of monoaromatic concentrates.

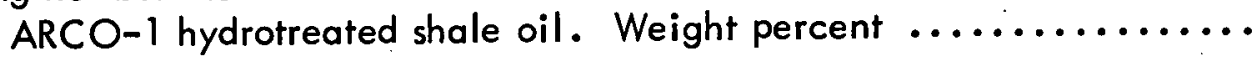

8. Ring number distribution of diaromatic concentrates.
ARCO-1 hydrotreated shale oil. Weight percent

9. Ring number distribution of polyaromatic-polar concentrates.

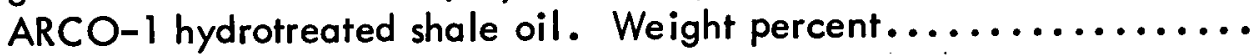




\title{
CHARACTERIZATION OF HYDROTREATED \\ TOSCO SHALE OIL
}

\author{
by \\ J. W. Vogh, ${ }^{1}$ S. A. Holmes, ${ }^{1}$ G. P. Sturm, Jr., ${ }^{1}$ \\ P. W. Woodward, ${ }^{1}$ and J. E. Dooley ${ }^{2}$
}

\begin{abstract}
A shale oil that had been produced by the TOSCO-II process and hydrotreated was characterized according to its hydrocarbon and other functional compound composition. The oil was separated by distillation, adsorption chromatography, acid and base extraction, and gel permeation chromatography into fractions suitable for mass spectral characterization. The oil was composed largely of saturate hydrocarbons with the remainder being mostly monoaromatic and diaromatic hydrocarbons. Very small amounts of heterocompounds were present.
\end{abstract}

\section{INTRODUCTION}

Shale oil is one of the potentially important fossil fuels that may supplement or replace petroleum in future years. Several processes based on retorting either in-place or aboveground have been developed for shale oil production. Reviews of these methods $(17,18),{ }^{3}$ as they are applied to oil shale resources of the western mountain states, are available.

Shale oil composition and processes suitable for its production appear to depend strongly upon the shale source $(6,18,19)$. However, products of western oil shale retorting are relatively uniform, with the only significant differences noted between the classes of products from the in-place retorting methods and those from aboveground methods (ㅁ) .

1 Research chemist.

2 Project leader.

3 Underlined numbers in parentheses refer to items in the list of references at the end of this report. 
The characteristic of typical shale oil that presents the greatest problem in further processing and utilization is its high nitrogen content. A recent review of shale oil composition and refining (13) treats this subject in detail. Hydrotreating processes have been used to reduce nitrogen as well as to remove oxygen and sulfur. Since nitrogen is more difficult to remove than oxygen or sulfur, characterization of nitrogen compounds and their response to hydrotreating have received the major share of attention in studies of compound characterization $(\underline{2}, \underline{4}, \underline{5}, \underline{14}, \underline{15})$.

Studies on hydrocarbon composition have been less extensive, but some work has been done on raw shale oil and on hydrotreated samples $(3,14,16)$. Ruberto $(16)$ reported a relatively detailed hydrocarbon analysis for distillate cuts obtained from raw TOSCO shale oil. Peters and Bendoraitis (14) present a brief comparison of raw and hydrotreated TOSCO oil.

Shale oil must be modified by hydrotreating, coking, and other processes to an extent necessary to make it suitable for conventional petroleum refining conditions. Objectives of hydrocarbon characterization studies are the determination of native hydrocarbons that may be carried through the processing unchanged or altered by hydrotreating and other steps and the hydrocarbons formed by destruction of the original heterocompounds. Since hydrotreating of hydrocarbons is not necessarily desired at this stage of processing, the hydrotreating and other steps need be no more severe than required for nitrogen compound control. Without detailed characterization of the hydrocarbons and heterocompounds of the raw shale oil it is not possible to determine the probable origin of hydrocarbons in the final product. However, to the extent that the processed shale oil represents a typical product of denitrogenation and other treatment, hydrocarbon analysis is useful.

The shale oil characterized in this study was supplied by the Atlantic Richfield Co. (ARCO). It was material theit had been processed by ARCO from raw shale oil obtained -from The Oil Shale Corp. by the TOSCO-II process. Unfortunately, details of the processing are not available. It was represented as hydrotreated material, and examination of physical properties and distillation data indicate that the raw shale oil may have been coked before hydrotreatment.

The characterization scheme used in this study is essentially the same as that used in this laboratory in work with petroleum residues and coal liquefaction products $(\underline{7}, \underline{8}, 11,21,22$, $23,24)$. This involves distillation to cuts of predetermined limits, class separation by adsorption chromatography, isolation of acidic and basic groups, further separation by gel permeation chromatography, and characterization by mass spectral analysis. The only change from previous sample processing was in the use of different distillation equipment and method. This is discussed in the experimental and results sections. 


\section{EXPERIMENTAL}

\section{Routine Analysis and Physical Data}

Samples of the ARCO hydrotreated shale oil (ARCO-1) were submitted to the usual examination given to petroleums and similar materials. These procedures are ASTM or other standardized methods suitable for characterization of the properties of petroleum oils.

Separations

Distillation

The first step in the separation scheme for the shale oil was distillation to produce closely defined fractions. This was carried out in a metal mesh spinning band still (Perkin-Elmer). ${ }^{4}$ In comparison with other fractional distillation equipment, this still provides efficient separation at low pressure as well as relatively high throughput. Conditions for distillation to selected cut points were determined by examination of a high-paraffin broad boiling range sample. Samples from distillation of this material were analyzed by gas chromatography to establish the paraffin carbon number and overlap range. Boiling point cut temperatures were assigned as the paraffin atmospheric boiling points for the paraffins detected at the beginning and end of the chromatograms. In general, there was an overlap of residue and distillate of only about one paraffin carbon number, and the exact boiling point was scaled between the atmospheric boiling points of these paraffins in proportion to the fraction of each in the distillate.

\section{Adsorption Column Separations}

With the exception of material boiling below $200^{\circ} \mathrm{C}$, the distillate fractions and the residue were subjected to silica-alumina column separation (9). This produces fractions consisting of (a) saturate hydrocarbons, (b) monoaromatic hyd̆rocarbons, (c) diaromatic hydrocarbons, and (d) polyaromatic and polar materials. Samples of about 45 grams of each distillate or residue were processed by the adsorption column method to obtain sufficient quantities of each class fraction for further separations and characterization. The material boiling below $200^{\circ} \mathrm{C}$ was not carried through the silica-alumina column procedure because of difficulty in recovery of volatile materials from this procedure. Instead, a preliminary liquid chromatograph procedure on silica gel at reduced temperature (8) was carried out. The objective in this procedure was detection of saturate, aliphatic olefin, monoaromatic, and diaromatic hydrocarbons.

4 Mention of brand names for identification only and does not imply endorsement by DOE. 


\section{Isolation of Acidic and Basis Compounds}

Acids and bases were removed from the first distillate (below $200^{\circ} \mathrm{C}$ ) and from the polyaromatic-polar (PAP) concentrates excepting the $200^{\circ}$ to $325^{\circ} \mathrm{C}$ PAP concentrate. The procedure involved extraction with dilute $\mathrm{NaOH}$ or $\mathrm{HCl}$ in methanol-water $(2: 1)$ as applied previously ().

\section{Gel Permeation Chromatography}

All monoaromatic, diaromatic, and polyaromatic concentrates from the adsorption column separations were further separated by gel permeation chromatography (GPC) on styragel (10). In this procedure, samples were collected in uniform increments to permit preparation of mass chromatograms of the samples and to provide material for mass spectral characterization on a normalized weight basis.

\section{Characterization}

The distillate boiling below $200^{\circ} \mathrm{C}$ was characterized by mass spectrometry according to an ASTM procedure (1). This method determines saturate and monoaromatic hydrocarbons and was considered to be suitable for this sample because prior examination had shown it to be free of acids, olefins, and diaromatic hydrocarbons and to contain only a trace $(\sim 0.01$ percent) of bases.

Saturate hydrocarbon concentrates of the higher boiling and residue fractions were analyzed by high-voltage, low-resolution mass spectrometry, and the results of this were interpreted by the matrix techniques of $t$ Hood and $O^{\prime} \mathrm{Neal}(12)$. This technique yields results for saturate characterization in terms of naphthene ring number plus alkylbenzenes. The evaluation procedure is adjusted for each sample to produce best results. Carbon numbers assigned to the matrix analysis method are $\mathrm{C}_{12}$ for the $200^{\circ}$ to $325^{\circ} \mathrm{C}$ sample, $\mathrm{C}_{19}$ for the $325^{\circ}$ to $425^{\circ} \mathrm{C}$, and $\mathrm{C}_{28}$ for the iesidue sample.

No similar method exists for the monoaromatic, diaromatic, and polyaromatic-polar materials. These samples were therefore analyzed by means of low-voltage, low-resolution mass spectrometry of selected GPC subfractions of each of these concentrates. Results were compiled and characterizations established on the basis of detailed correlations of gel permeation separation with mass spectra (10).

Heterocompounds in the GPC subfractions were identified by means of high-resolution mass spectrometry. 


\section{RESULTS AND DISCUSSION}

\section{Preliminary Examination}

Gross physical analysis and elemental analysis for sulfur and nitrogen for the whole hydrotreated shale oil are shown in table 1. Certain notable features of this preliminary data report can be compared to those in reports on petroleums $(21,23)$ and on coal liquefaction products $(\underline{8}, 11,22,24)$. Sulfur and nitrogen levels are very low in comparison with the petroleums and coaThiquids. Crude shale oil would be expected to have high nitrogen content in particular, and the low level found here is probably indicative of the extent of refining by hydrotreating. The values and trend of the correlation index (C.I.) are similar to those of petroleums $(20)$ and quite different from those of the coal liquids. Refractive index and specific gravity are less discriminating than correlation index but support the same conclusions. In general these physical measurements indicate a more saturated and naphthenic character for the hydrotreated shale oil than for the coal liquids.

The residuum value is low in comparison to petroleums but similar to that of coal liquids. This is due to distillation in the conversion processes.

\section{Separations}

Distillation yields and selected physical and elemental analysis for each distillate are shown in table 2. The successive distillate fractions had an overlap of one to two n-paraffin carbon numbers. Figure 1 shows gas chromatograms of indicated fractions.

The distillates boiling above $200^{\circ} \mathrm{C}$ and the residue were processed by adsorption column chromatography, as described in the experimental section, to produce hydrocarbon class concentrates. Table 3 shows the weight-percent yield of the various classes in each distillate range. In comparison with the petroleum and coal liquids mentioned earlier, this sample has more saturates and less of the higher aromatics.

Acids and bases were a very small part of the ARCO-1 hydrotreated shale oil. Table 4 shows the amounts in terms of weight percentage of the original distillate fractions. Only the acids and bases recovered from the $325^{\circ}$ to $425^{\circ} \mathrm{C}$ fraction were sufficient in amount to permit further characterization.

Figure 2 shows the GPC chromatograms for the aromatic concentrates of fractions boiling above $200^{\circ} \mathrm{C}$. The quantity of the polyaromatic-polar concentrate of the $200^{\circ}$ to $325^{\circ} \mathrm{C}$ fraction was insufficient to allow useful characterization and was not carried through the GPC separation. Each figure shows weight percent recovery in a collected sample versus the retention volume of the sample. Substantially all of each concentrate was recovered. 
TABLE 1. - Preliminary data of ARCO-1 hydrotreated shale oil

Shale Oil (Hydrotreated)

TOSCO If Process

ARCO- 1

GENERAL CHARACTERISTICS

Gravity, specific,

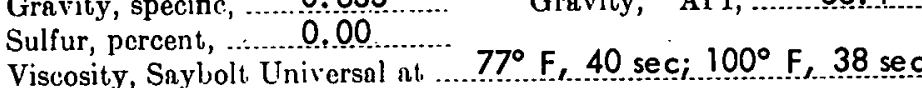

Gravity, ${ }^{\circ}$ API, .........38. 4

Pour point, ${ }^{\circ} \mathrm{F}, 60$

Color, ...brownish green

Nitrogen, percent, ...... 0.037

DISTILLATION, BUREAU OF MINES ROUTINE METHOD

StAOE 1-Distillation at atmospheric pressure, .....740 .... mm. $\mathrm{Hg}$

First drop. ....201...... ${ }^{\circ} \mathrm{F}$.

\begin{tabular}{|c|c|c|c|c|c|c|c|c|c|c|}
\hline $\begin{array}{l}\text { Fraction } \\
\text { No. }\end{array}$ & $\begin{array}{c}\text { Cut } \\
\text { tompp. } \\
\text { om. }\end{array}$ & Percent & $\underset{\text { perecill }}{\text { Sum. }}$ & $\begin{array}{l}\text { Sp. gr. } \\
60 / 60^{\circ} \cdot \mathbf{F}\end{array}$ & ${ }_{6}^{\circ}{ }_{6}^{A} \mathrm{FI}$. & C. I. & $\begin{array}{l}\text { Refractive } \\
\text { index } \\
n_{\text {D }} \text { at } 20^{\circ} \mathrm{C} \text {. }\end{array}$ & $\begin{array}{c}\text { Specific } \\
\text { dispersion }\end{array}$ & $\begin{array}{c}\text { S. U. } \\
\text { visc. } \\
100^{\circ} \mathbf{F} . \\
\end{array}$ & $\begin{array}{c}\text { Cloud } \\
\text { test. } \\
\text { of. }\end{array}$ \\
\hline $1 \ldots \ldots$ & 122 & & & & & & & $\therefore$ & \multirow{11}{*}{. } & \\
\hline 2 & 167 & & & & & & & & & \\
\hline . & 212 & & & & & & & & & \\
\hline $4 \ldots$ & 257 & 5.! & 5.1 & 0.739 & 60.0 & - & 1.41289 & 135.1 & & \\
\hline $5 \ldots$ & 302 & 7.2 & 12.3 & 759 & 54.9 & 23 & 1.42267 & 1363 & & \\
\hline & 347 & 6.9 & 19.2 & 780 & 49.9 & 26 & 1.43273 & 1389 & & \\
\hline $7 \ldots \ldots$ & 392 & 9.0 & 28.2 & .795 & 46.5 & 27 & 1.44162 & 140.3 & & \\
\hline $8 \ldots \ldots$ & 437 & 8.2 & 36.4 & .813 & 42.6 & 30 & 1.45113 & 143.0 & & \\
\hline $0 \ldots \ldots$ & 482 & 10.0 & 46.4 & .829 & 39.2 & 32 & 1.45908 & 146.7 & & \\
\hline $10 \ldots \ldots$ & 527 & 7.6 & 54.0 & 843 & 36.4 & 34 & 1.46643 & 147.9 & & \\
\hline & & & & & & & & & & \\
\hline
\end{tabular}

STAGE 2-Distillation continued at $40 \mathrm{~mm}$. $\mathrm{Hg}$

\begin{tabular}{|c|c|c|c|c|c|c|c|c|c|c|}
\hline & & 8.1 & 62.1 & 0.855 & 34.0 & 36 & 1.47457 & 149.0 & 41 & 10 \\
\hline 12 & 437 & 9.6 & 71.7 & .860 & 33.0 & 35 & 1.47863 & 151.9 & .46 & 34 \\
\hline 13 & 482 & 7.7 & 79.4 & .865 & .32 .1 & 34 & 1.48434 & 152.6 & 59 & .56 \\
\hline$/ 14$ & 527 & 3.4 & 82.8 & 876 & 30.0 & - & 1.488 .58 & - & .76 &. .76 \\
\hline $\begin{array}{l}15 \ldots \ldots \\
\text { Residuum }\end{array}$ & 572 & 16.8 & 99.6 & .903. & 25,2 & & & & & \\
\hline
\end{tabular}

Carbon residue, Conradson: Residuum, 2.0. percent; crude, 0.4 ... percent.

APPROXIMATE SUMMARY

Residuum:

Sulfur, percent, ......... 0.005

Nitrogen, percent, ... 0.121

\begin{tabular}{|c|c|c|c|c|}
\hline & Percent & Sp. gr. & $\circ$ API & Viscosity \\
\hline 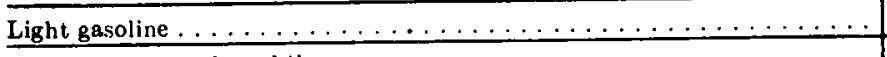 & & & & \\
\hline Total gasoline and naphtha $\ldots \ldots \ldots \ldots \ldots \ldots \ldots$ & 28.2 & $0 . \overline{772}$ & 51.8 & \\
\hline Kerosine distillate $\ldots \ldots \ldots \ldots \ldots \ldots \ldots \ldots \ldots \ldots \ldots \ldots$ & 8.2 & .813 & 42.6 & \\
\hline 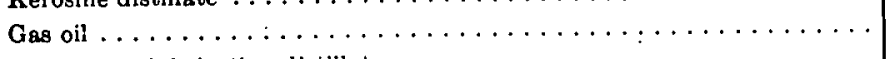 & 36,4 . & .847 & 35.6 & \\
\hline Nonviscous lubricating distillate $\ldots \ldots \ldots \ldots \ldots \ldots \ldots$ & 10.0 & $.863-.879$ & $32.5-29 . .5$ & $50-100$ \\
\hline Medium lubricating distillate $\ldots \ldots \ldots$ & $\therefore$ & $\therefore$ & $-\ldots$ & $100-200$ \\
\hline Viscous lubricating distillate $\ldots \ldots \ldots \ldots \ldots \ldots \ldots \ldots$ & 9 & - & $\therefore$ & Above 200 \\
\hline 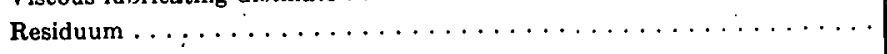 & 16.8 & 903 & 25.2 & \\
\hline Distillation los: & & & & \\
\hline
\end{tabular}

1/ Distillation discontinued at $500^{\circ} \mathrm{F}$. 


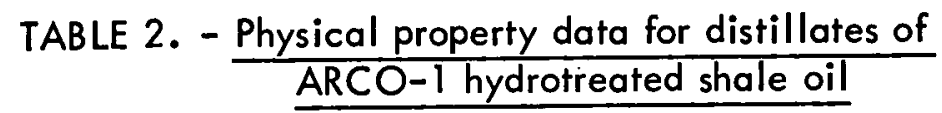

\begin{tabular}{|c|c|c|c|c|}
\hline \multirow[b]{2}{*}{ Property } & \multicolumn{4}{|c|}{ Distillates } \\
\hline & $<200^{\circ} \mathrm{C}$ & $200-325^{\circ} \mathrm{C}$ & $325-425^{\circ} \mathrm{C}$ & $>425^{\circ} \mathrm{C}$ \\
\hline Distillate yield, wt-pct. ........ & 26.9 & 40.6 & 22.7 & 9.5 \\
\hline Specific gravity, $60 / 60^{\circ} \mathrm{F} \ldots \ldots$ & 0.773 & 0.842 & 0.881 & 0.894 \\
\hline Gravity, ${ }^{\circ} \mathrm{API}, \ldots \ldots \ldots \ldots \ldots$ & 51.6 & 36.6 & 29.1 & 26.8 \\
\hline Pour point ${ }^{\circ} \mathrm{F}, \ldots \ldots \ldots \ldots \ldots$ & - & -14.5 & 60 & - \\
\hline $\begin{array}{l}\text { Kinematic viscosity } \ldots \ldots \ldots \ldots \ldots \\
\text { at } 100^{\circ} \mathrm{F}, \mathrm{C}_{\mathrm{s}}\end{array}$ & $<32$ & 35 & - & - \\
\hline $\begin{array}{l}\text { Saybolt viscosity } \ldots \ldots \ldots \ldots \ldots \ldots \\
\text { at } 100^{\circ} \mathrm{F} \text {, SUS }\end{array}$ & - & - & 77 & - \\
\hline $\begin{array}{l}\text { Refractive index } \ldots \ldots \ldots \ldots \ldots \ldots \\
N_{D} \text { at } 20^{\circ} \mathrm{C}\end{array}$ & 1.42936 & 1.46659 & - & - \\
\hline Sulfur, percent $\ldots . . \ldots \ldots \ldots \ldots$ & 0.00 & 0.00 & 0.00 & 0.02 \\
\hline Nitrogen, percent ....... & 0.004 & 0.029 & 0.091 & 0.093 \\
\hline $\begin{array}{c}\text { Carbon residue } \\
\text { (Conradson) }\end{array}$ & - & - & - & Negligible \\
\hline
\end{tabular}

TABLE 3. - Yields in adsorption chromatography of ARCO-1 hydrotreated shale oil fractions, weight percent

\begin{tabular}{l|c|c|c}
\hline \multirow{2}{*}{\multicolumn{1}{c|}{ Class }} & \multicolumn{3}{|c}{ Fraction, wt percent yield } \\
\cline { 2 - 4 } \multicolumn{1}{c}{} & $200^{\circ}-325^{\circ} \mathrm{C}$ & $325^{\circ}-425^{\circ} \mathrm{C}$ & $>425^{\circ} \mathrm{C}$ \\
\hline Saturate & 73.11 & 68.74 & 76.73 \\
Monoaromatic & 22.19 & 18.12 & 13.72 \\
Diaromatic & 2.47 & 6.05 & 3.50 \\
Polyaromatic-polar & 1.40 & 7.01 & 7.54 \\
(Lost) & .83 & .09 & $1-1.49$ \\
\hline
\end{tabular}

1 Gain over 100 percent recovery. 

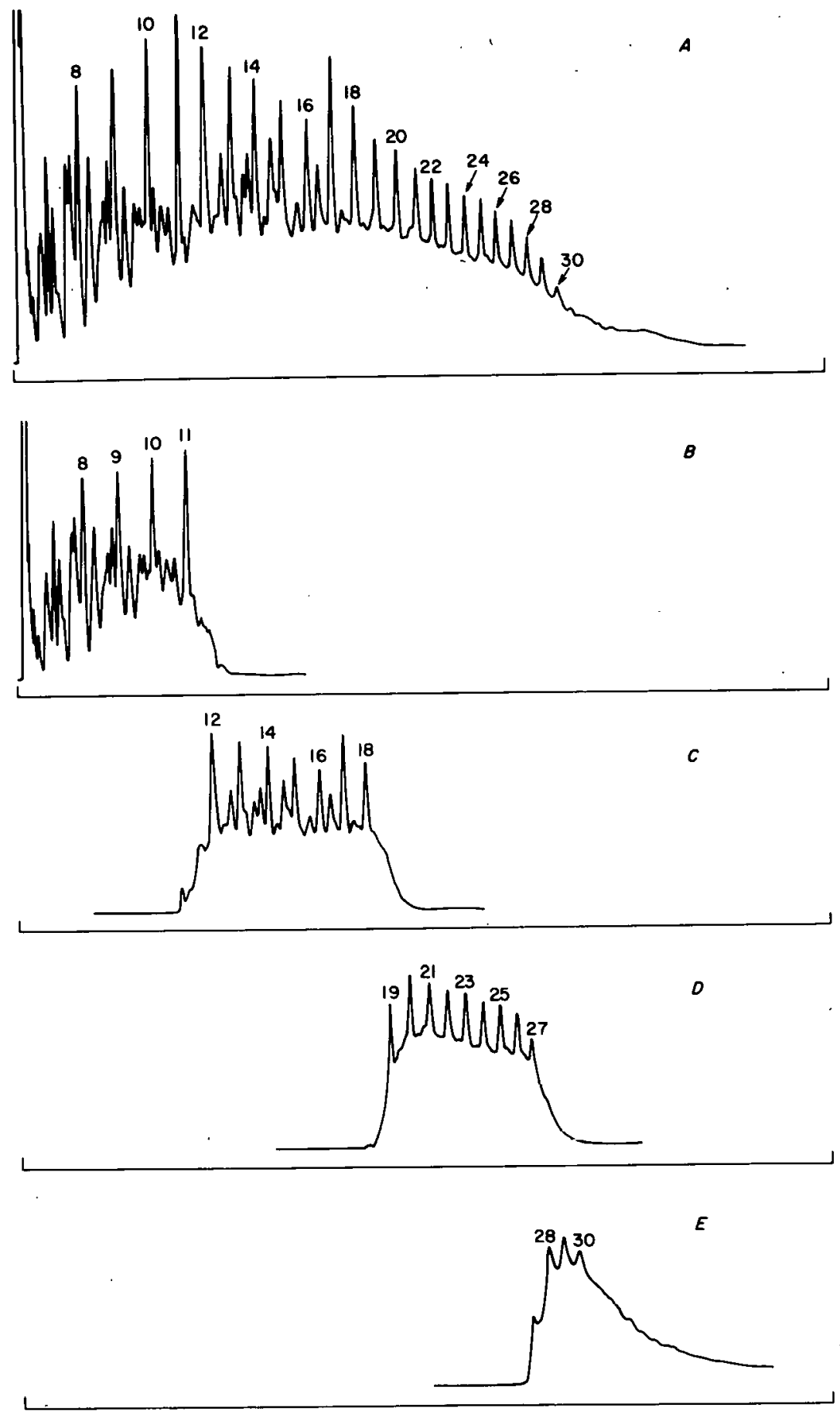

FIGURE 1. - Gas chromatograms of hydrotreated Tosco shale oil (ARCO-1). A. Whole oil sample, B. Distillate below $200^{\circ} \mathrm{C}, \mathrm{C}$. Distillate 200-325 $\mathrm{C}$, D. Disti $\Pi_{\text {ate }} 325^{\circ}$ to $425^{\circ} \mathrm{C}$, E. Residue. Numbers above chromatograms indicate n-paraffins. Column: Dexsil 300 GC, 4 percent, $150 \mathrm{~cm}$ length. Programmed from $10^{\circ}$ to $350^{\circ} \mathrm{C}$ at $6^{\circ} \mathrm{C} / \mathrm{min}$. 
TABLE 4. - Acid and base concentrates obtained from polyaromaticpolar material. Weight percent of distillate fraction

\begin{tabular}{l|c|c|c}
\hline & \multicolumn{3}{|c|}{ Fraction } \\
\cline { 2 - 4 } & $200^{\circ}-325^{\circ} \mathrm{C}$ & $325^{\circ}-425^{\circ} \mathrm{C}$ & $>425^{\circ} \mathrm{C}$ \\
\hline Acids & nil & 0.20 & 0.05 \\
Bases & nil & 0.10 & 0.05 \\
\hline
\end{tabular}

The chromatogram peak widths of the concentrates are slightly narrower than those obtained in previous work. This may be due to the improved distillation fractionation of this work which produced samples with reduced content of material beyond the specified boiling range limits. Retention volumes at peak value for the concentrates slightly greater than ordinarily found $(11,21,22,24)$ for equivalent boiling range material. No firm interpretation can be made but it may be due to decreased amounts of long $n$-alkyl side chains.

\section{Characterization}

\section{Distillate Below $200^{\circ} \mathrm{C}$}

The composition study of the distillate fraction boiling below $200^{\circ} \mathrm{C}$ was carried out by procedures different from those applied to the remainder of the fractions because of its relative simplicity and its high volatility. Acid and base extraction showed that it contained no acids and no more than a trace of bases. Likewise, liquid chromatography on silica showed that olefins and naphthalenes were absent. Therefore this fraction was suitable without further treatment for mass spectral characterization of the gasoline hydrocarbons.

Table 5 shows the composition of the low boiling distillate in terms of ring number for the saturates and aromatics. In keeping with the usual form in previous reports on petroleums and coal liquids, results are given in terms of weight percentage of distillate fraction and of original oil. Average carbon numbers by mass spectrometry were 8.51 for the saturates and 8.45 for the aromatics.

TABLE 5. - Hydrocarbon composition of distillate boiling below $200^{\circ} \mathrm{C}$

\begin{tabular}{|c|c|c|}
\hline $\begin{array}{l}\text { Hydrocarbon } \\
\text { Type }\end{array}$ & $\begin{array}{c}\text { Distillate, } \\
\text { weight percent }\end{array}$ & $\begin{array}{c}\text { Shale oil, } \\
\text { weight percent }\end{array}$ \\
\hline $\begin{array}{l}\text { Paraffins } \ldots \ldots \ldots \ldots \ldots \ldots \ldots \ldots \ldots \ldots \\
\text { Monocyclo-paraffins } \ldots \ldots \ldots \ldots \ldots \ldots \ldots \ldots \ldots \ldots \\
\text { Dicyclo-paraffins } \ldots \ldots \ldots \ldots \ldots \ldots \ldots \ldots \ldots \ldots \\
\text { Alkylbenzenes } \ldots \ldots \ldots \ldots \ldots \ldots \ldots \ldots \ldots \\
\text { Indans and tetralins } \ldots \ldots \ldots \ldots \ldots \ldots \ldots\end{array}$ & $\begin{array}{r}51.94 \\
31.02 \\
4.47 \\
10.93 \\
1.64\end{array}$ & $\begin{array}{r}13.97 \\
8.34 \\
1.20 \\
2.94 \\
.44\end{array}$ \\
\hline
\end{tabular}



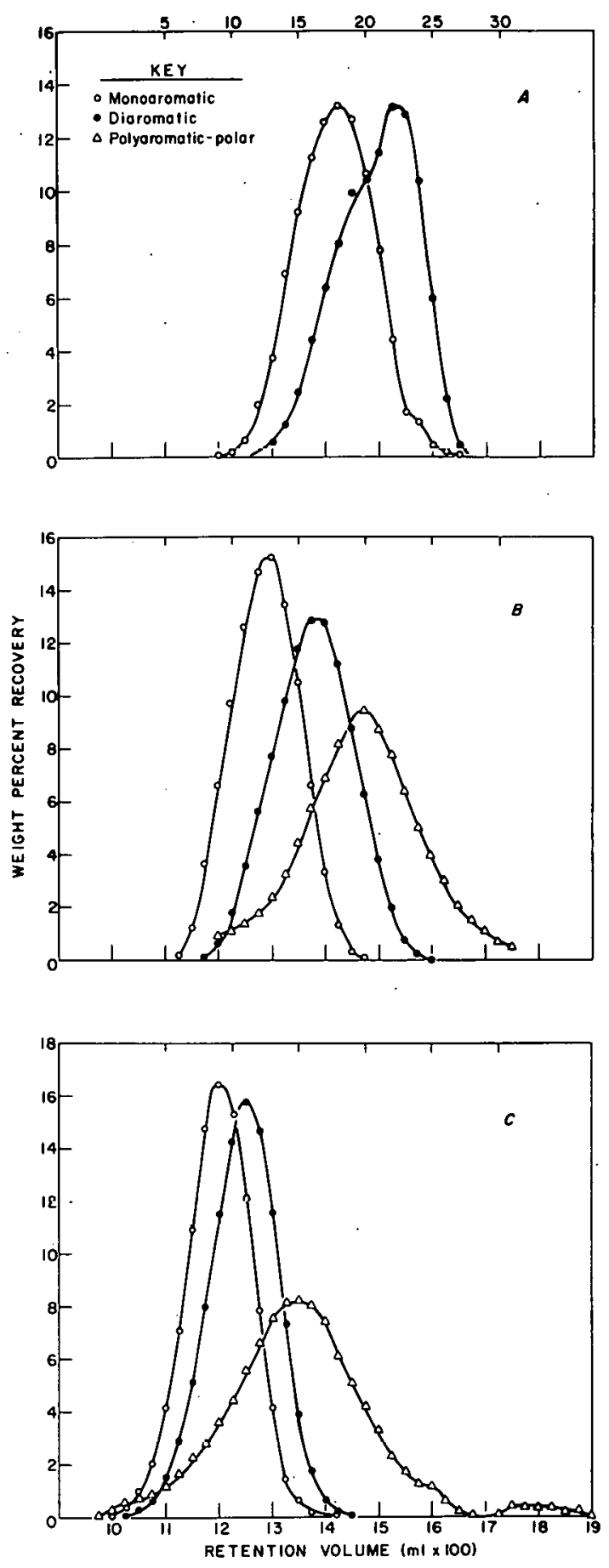

FIGURE 2. - Gel permeation chromatograms of aromatic concentrates of ARCO-1 shale oil. A) From $200^{\circ}-325^{\circ} \mathrm{C}$ distillate, B) From $325^{\circ}-425^{\circ} \mathrm{C}$ distillate, and C) From $>425^{\circ} \mathrm{C}$ iesidue. 


\section{Saturates}

Saturate hydrocarbons were characterized by mass spectral examination of the concentrates obtained from adsorption column separation. Table 6 shows the amounts of the various ring number classes in the $200^{\circ}$ to $325^{\circ} \mathrm{C}$ and $325^{\circ}$ to $425^{\circ} \mathrm{C}$ distillates and the $>425^{\circ} \mathrm{C}$ residue. Results are given on the basis of percentage in the concentrates and percentage in the whole oil. The carbon-number matrix used in determination of ring distribution of each concentrate is indicated in table 6.

TABLE 6. - Ring number distribution of saturate concentrates ARCO-1 hydrotreated shale oil, weight percent

\begin{tabular}{|c|c|c|c|c|c|c|}
\hline \multirow[b]{2}{*}{ Rings } & \multicolumn{2}{|c|}{$200^{\circ}-325^{\circ} \mathrm{C}$} & \multicolumn{2}{|c|}{$325^{\circ}-425^{\circ} \mathrm{C}$} & \multicolumn{2}{|c|}{ Residue } \\
\hline & Concentrate & Shale oil & Concentrate & Shale oil & Concentrate & Shale oil \\
\hline 0 & 40.4 & 11.99 & 41.5 & 6.48 & 38.7 & 2.82 \\
\hline 1 & 25.8 & 7.66 & 24.7 & 3.85 & 22.6 & 1.65 \\
\hline 2 & 23.0 & 6.83 & 14.8 & 2.31 & 10.1 & .74 \\
\hline 3 & 7.6 & 2.26 & 9.5 & 1.48 & 15.8 & 1.15 \\
\hline 4 & 1.9 & .56 & 9.0 & 1.40 & 5.9 & .43 \\
\hline 5 & 1.3 & .39 & 0.5 & .08 & 3.1 & .23 \\
\hline 6 & - & - & - & - & 3.1 & .23 \\
\hline $\begin{array}{l}\text { Mono- } \\
\text { aromatic }\end{array}$ & - & - & - & - & 0.7 & .05 \\
\hline $\begin{array}{l}\text { C number } \\
\text { matrix }\end{array}$ & 12 & & 19 & & 28 & \\
\hline
\end{tabular}

The amounts of zero-ring saturates are somewhat large in comparison with both perroleum and coal liquid samples of equivalent boiling range $(7,8,11,21,22,23,24)$. Amounts of four and higher ring saturates are much smaller than in almost al other samples. This is particularly notable in the residue fraction. There is a similarity to the Utah coal syncrude (8) residue in the prominence of the three-ring class.

\section{Monoaromatic Hydrocarbons}

Monoaromatics were characterized by means of low-voltage, low-resolution mass spectral analysis of selected gel permeation fractions of the monoaromatic class concentrates. These analytical results on GPC fractions were combined to yield overall compositions of 
the monoaromatic concentrates. Table 7 shows the results in terms of ring number classes for the $200^{\circ}$ to $325^{\circ} \mathrm{C}$ and $325^{\circ}$ to $425^{\circ} \mathrm{C}$ distillates and the $>425^{\circ} \mathrm{C}$ residue.

The zero naphthene ring class is again more prominent in the ARCO-1 shale oil than in coal liquids and petroleum residues. The principal naphtheno-monoaromatic class in coal liquid residues has been the three ring group $(8,22,24)$. The $\mathrm{H}$-Coal $(11)$ product more closely resembles the ARCO-1 shale oil, but comparison is difficult since the distillation ranges do not correspond. Petroleum residues $(7,21)$ showed two and three naphtheno ring classes as the most prominent monoaromatics.

High resolution mass spectral examination of GPC fractions of the $325^{\circ}$ to $425^{\circ} \mathrm{C}$ and residue materials confirmed the hydrocarbon identities and the virtual absence of heterocompounds.

\section{Diaromatic Hydrocarbons}

Table 8 shows the results of low-voltage, low-resolution mass spectral examination of selected GPC diaromatic fractions. Overall compositions shown were obtained by combination of mass spectra results weighted for the percent sample recovery in the individual GPC fractions. Results are shown for all fractions above $200^{\circ} \mathrm{C}$.

The zero naphtheno ring class is more prominent in the ARCO-1 shale oil than in equivalent distillate fractions of coal liquids or petroleums. Other than this, there are no significant differences of general nature.

High-resolution mass spectra again confirmed hydrocarbon identifications and the near absence of heterocompound classes.

\section{Polyaromatic-Polar Material}

The PAP concentrate of the $200^{\circ}$ to $325^{\circ} \mathrm{C}$ distillare was insufficient to allow useful GPC and mass spectral examination. Table 9 shows results of low-voltage low-resolution mass spectral examination of selected GPC fractions of PAP material for the $325^{\circ}$ to $425^{\circ} \mathrm{C}$ and $>425^{\circ} \mathrm{C}$ residue. Strong acids and bases had been removed from the PAP concentrates prior to this analysis.

The hydrocarbon composition in these concentrates is fairly similar to that found in some of the petroleum and coal liquids. Since PAP composition varies over a wide range for different oil samples, no special character can be assigned to the ARCO-1 shale oil. The heterocompound character is somewhat simpler than generally found for PAP samples since it is free of sulfur compounds and contains a relatively small amount of nitrogen compounds.

Hydrocarbon and nitrogen compound compositions were confirmed by high-resolution mass spectra. 
TABLE 7. - Ring number distribution of monoaromatic concentrates

ARCO-I hydrotreated shale oil, weight percent

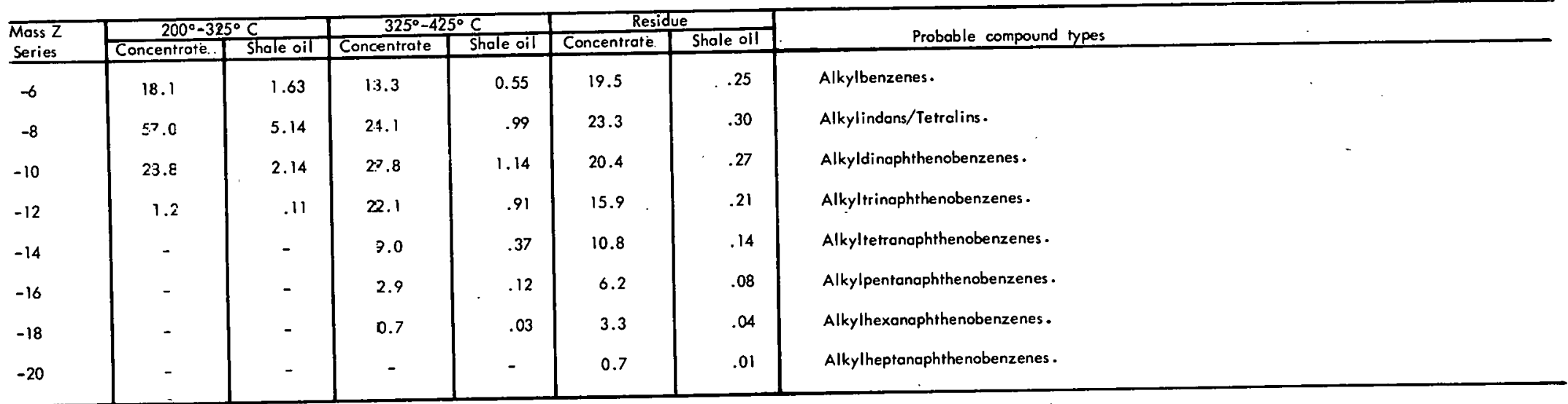

TABLE 8. - Ring number distribution of diaromatic concentrates ARCO-1 hydrotreated shale oil, weight percent

\begin{tabular}{|c|c|c|c|c|c|c|c|}
\hline $\begin{array}{l}\text { Mass Z } \\
\text { Series } \\
\end{array}$ & \multicolumn{2}{|c|}{$200^{\circ}-325^{\circ} \mathrm{C}$} & \multicolumn{2}{|c|}{$325^{\circ}-425^{\circ} \mathrm{C}$} & \multicolumn{2}{|c|}{ Residue } & \multirow{2}{*}{ Probable compound types } \\
\hline-10 & - & - & com & 0.02 & - & & \\
\hline-12 & 55.6 & & 11.3 & & & 03 & $\begin{array}{l}\text { Alkylnaphthalenes. } \\
\text { Alkylo }\end{array}$ \\
\hline & 23.0 & & 11.3 & .10 & 9.6 & .03 & Alkylnaphthenonaphthalenes and/or Alkyldiphenylalkanes. \\
\hline $\begin{array}{l}-14 \\
-16\end{array}$ & $\$ 2.4$ & .43 & 35.2 & .48 & 16.5 & .05 & Alkyldinaphthenonophthalenes and/or Alkylnaphthenodiphenylalkanes. \\
\hline-16 & 2.0 & .02 & 33.2 & .46 & 21.9 & .07 & Alkyltrinophthenonaphthalenes and/or Alkyldinaphthenodiphenylalkanes. \\
\hline-18 & - & - & 12.1 & .17 & 19.9 & .07 & Alkyltetronaphthenonaphthalenes and/or Alkyltrinaphthenodiphenylalkanes. \\
\hline-20 & - & $\begin{array}{l}- \\
-\end{array}$ & 3.9 & .05 & 14.8 & .05 & Alkylpentanaphthenonaphthalenes and/or Alkylretranaphthenodiphenylalkones. \\
\hline-22 & - & - & 1.3 & .02 & 9.8 & .03 & Alkylhexanaphthenonaphthalenes and/or Alkylpentanophthenodipheynlalkones. \\
\hline-24 & - & - & .2 & .00 & 6.1 & .02 & Alkylheptanaphthenonophtholenes and/or Alkylhexanaphthenodiphenylolkanes . \\
\hline-26 & - & - & - & - & 1.4 & .00 & Alkylcarbozoles. \\
\hline$-1,-15(N)$ & - & - & .1 &.$\infty$ & - & - & Alkylnophthenocarbazoles. \\
\hline$-3,17 \quad(N)$ & 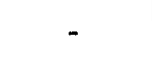 & - &.$\varepsilon$ & .01 & - & - & Alkyldinaphthenocarbazoles. \\
\hline$-5,-19(N)$ & - & - & .3 & .00 & - & & \\
\hline$\pi_{-1}$ & & & & & & & \\
\hline
\end{tabular}


TABLE 9. - Ring number distribution of polyaromatic-polar concentrates ARCO-l hydrotreated shale oil, weight percent

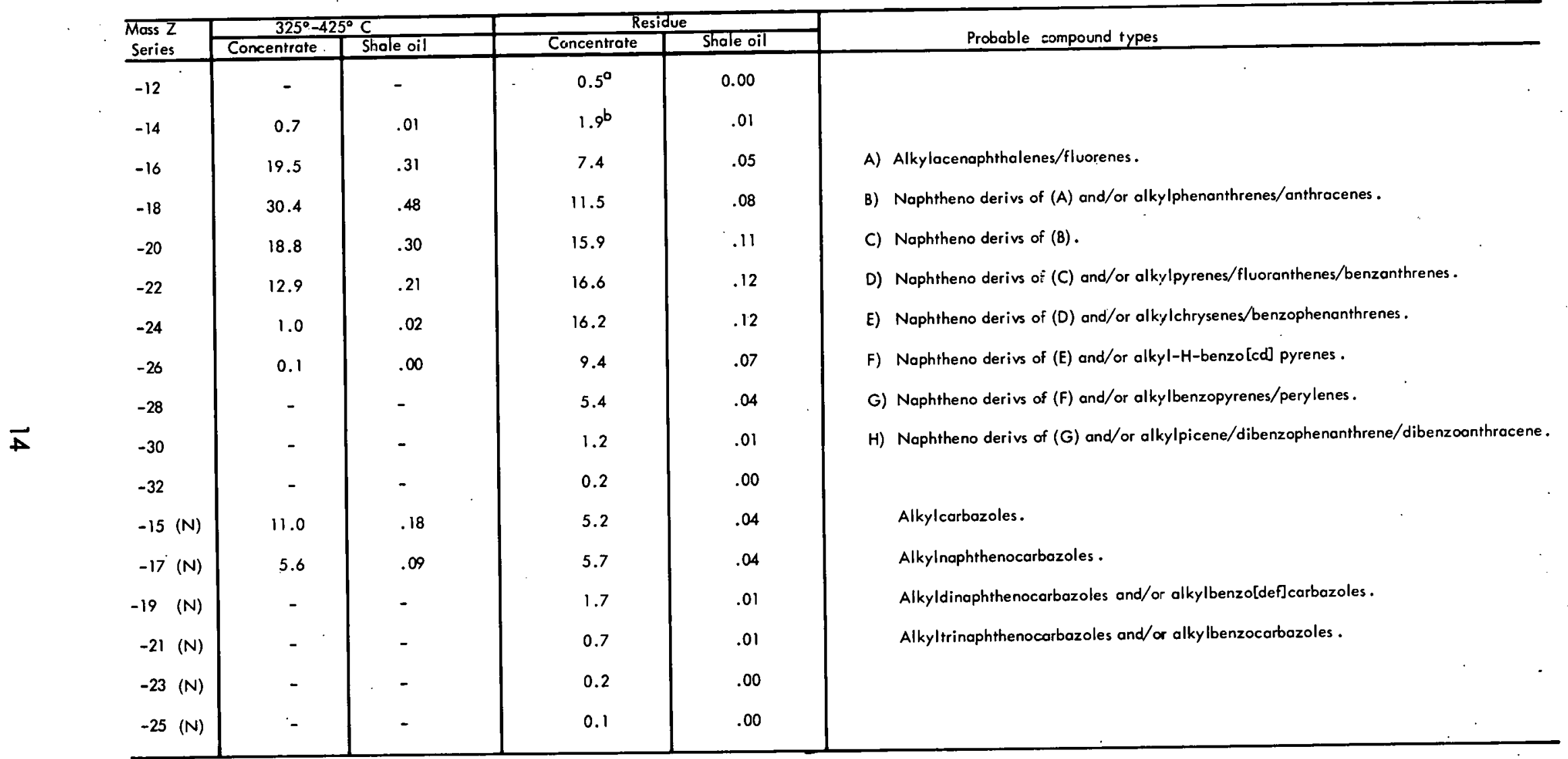

- Residue, $+2,-12$ unknown.

b Residue, 0,-14 unknown. 


\section{Acids and Bases}

As noted earlier, acids and bases were removed from the polyaromatic concentrates. Table 4 indicates that these fractions were quite small, and only the acids and bases of the $325^{\circ}$ to $425^{\circ} \mathrm{C}$ 'distillate were submitted to mass spectral examination. The acids fraction had an appreciable amount of hydrocarbon contamination. Most of the remainder consisted of oxygen compounds with small amounts of nitrogen and sulfur compounds. High resolution mass spectral data showed the series $-16(0)$ through $-24(0)$ and $-16\left(0_{2}\right)$ through $-22\left(\mathrm{O}_{2}\right)$. These correspond to hydroxy-substituted alkyl fluorenes, dinaphthonaphthalenes, and higher naphtheno derivatives of these. The highest $Z$-number classes correspond to hydroxy derivatives of pyrene and chrysene. The $\mathrm{O}_{2}$ class was present in very small amounts and correspond to carboxylic acids and dihydroxy derivatives of naphthenoaromatics.

The bases were relatively free of hydrocarbon contamination but contained some sulfur compounds. High-resolution mass spectral data showed the series $-5(N)$ through $-21(N)$ and -9 (NS) and -11 (NS). The lower $N$ series $(-5$ through -14$)$ corresponds to pyridine and quinoline bases and their naphtheno derivatives. Above -15 the series appears to correspond to carbazoles and higher related compounds with lesser amounts of acridines and related bases. The NS class was very small and could not be associated with any compound class group.

\section{CONCLUSIONS}

The overall composition of the ARCO-1 hydrotreated shale oil indicates a character of high saturation. Some outstanding points of comparison appear in the residue fraction. In this range, the sample has a higher level of saturates at 76.7 percent than any of the petroleum residues described in a previous comprehensive study (7) and a much higher level than any of the coal liquid residue saturates. Likewise, the sum of the diaromatic and polyaromatic-polar classes are lower than any of comparable petroleum and coal liquid residues. As far as comparisons are available, the same observations apply to the distillates. Saturates amounted to 76.1 percent of the original whole hydrotreated shale oil.

A still more striking characteristic of the ARCO sample is virtual absence of nitrogen and sulfur compounds. As far as possible, these compound classes were given full attention in the characterization procedures since their identities may serve as clues to the original shale oil composition. However, their actual amounts were so low that they can be considered unimportant in the hydrotreated shale oil.

Lacking any knowledge of the hydrotreating process, it is not possible to draw detailed conclusions on the composition of the original shale oil stock. The very low levels of nitrogen and sulfur indicate that the hydrotreating process was severe. The low levels of diaromatic and PAP concentrates could be attributed to either low levels in the original 
oil or to severe hydrotreating. If hydrotreating were the cause, a buildup of naphtheno ring classes in the monoaromatic concentrate would be expected. An unusually severe hydrotreating process would be required to carry these aromatics through to the saturate concentrate. In any case, the naphtheno ring classes of each concentrate tend toward low ring numbers. This could indicate that the observed hydrocarbon composition is roughly representative of the original oil. However, it appears equally probable that removal of nitrogen and sulfur from ring structures such as pyridine, pyrrole, and thiophene would yield lower aromatic and saturate hydrocarbon classes without increased naphtheno ring number, since that ring would be eliminated from the structure. Crude shale oils usually have high nitrogen levels.

In summary, the ARCO-1 hydrotreated shale oil has a rather unusual, highly saturated, and almost exclusively hydrocarbon composition. It is not clear to what extent this composition reflects the oil shale material, the conversion to crude shale oil, or the hydroprocessing that it received.

\section{REFERENCES}

1. American Society for Testing and Materials, Standard Test Method for Hydrocarbon Types in Low Olefinic Gasoline by Mass Spectrometry, ANSI/ASTM D2789-71 . 1976 Annual Book of ASTM Standards, Part 24, Petroleum Products and Lubricants, (11), ASTM, Philadelphia, PA, 1976, pp. 718-726.

2. Brown, D. G., Earnshaw, F. R. McDonald, and H. B. Jensen. Gas-Liquid Separation and Spectrometric Identification of Nitrogen Bases in Hydrocracked Shale Oil Naptha. Anal. Chem., v. 42, No. 2, February 1970, pp. 146-151.

3. Cady, W. E. and H. S. Seelig. Composition of Shale Oil. Ind. Eng. Chem., v. 44, No. 11, November 1952, pp. 2636-2641.

4. Cook, G. L. Nitrogen Compounds in Colorado Shale Oils. Amer. Chem. Soc., Div. of Petrol. Chem. Preprints, v. 10, No. 2, 1965, pp. C35-C38.

5. Cottingham, P. L. Distribution of Nitrogen in Hydrocracked In Situ Shale Oil. Ind. Eng. Chem., Prod. Res. Dev., v. 15, No. 3, 1976, pp. 197-201.

6. Dinneen, G. U., J. S. Ball, and H. M. Thorne. Composition of Crude Shale Oils. Ind. Eng. Chem., v. 44, No. 11, November 1952, pp. 2632-2635.

7. Dooley, J. E., D. E. Hirsch, C. J. Thompson, and C. C. Ward. Analyzing Heavy Ends of Crude (Comparison of Five Crude Oils), Hydrocarbon Processing, v. 53, No. 11, November 1974, pp. 187-194. 
8. Dooley, J. E., G. P. Sturm, Jr., P. W. Woodward, J. W. Vogh, and C. J. Thompson. Analyzing Syncrude from Utah Coal. BERC/RI-75/7, August 1975, $24 \mathrm{pp}$.

9. Hirsch, D. E., R. L. Hopkins, H. J. Coleman, F. O. Cotton, and C. J. Thompson. Separation of High-Boiling Petroleum Distillates Using Gradient Elution Through Dual-Packed (Silica Gel-Alumina Gel) Adsorption Columns. Anal. Chem., v. 44, No. 6, May 1972, pp. 915-919.

10. Hirsch, D. E., J. E. Dooley, and H. J. Coleman. Correlations of Basic Gel Permeation Chromatography Data and The ir Applications to High-Boiling Petroleum Fractions. BuMines RI 7875, 1974, 77 pp.

11. Holmes, S. A., P. W. Woodward, G. P. Sturm, Jr., J. W. Vogh, and J. E. Dooley. Characterization of Coal Liquids Derived from the H-Coal Process. BERC/RI-76/10, November 1976, 32 pp.

12. Hood, A. and M. J. O'Neal. Status of Application of Mass Spectrometry to Heavy Oil Analysis. Advances in Mass Spectrometry, ed. by J. D. Waldron, Pergamon Press, New York, NY, 1959, pp. 175-192.

13. Lanning, W. C. The Refining of Shale Oil. BERC/IC-77/3. In press.

14. Peters, A. W. and J. G. Bendoraitis. High Resolution Mass Spectrographic Method for the Analysis of Nitrogen- and Oxygen-Containing Material Derived from Petroleum. Anal. Chem., v. 48, No. 7, June 1976, pp. 968-973.

15. Poulson, R. E., C. M. Frost, and H. B. Jensen. Characteristics of Synthetic Crude from Crude Shale Oil Produced by In Situ Combustion Retorting. Amer. Chem. Soc., Advances in Chemistry, v. 151, 1976, pp. 1-10.

16. Ruberto, R. G., D. M. Jewell, R. K. Jensen, and D. C. Cronauer. Characterization of Synthetic Liquid Fuels. Amer. Chem. Soc., Advances in Chemistry, v. 151, 1976, pp. 28-47.

17. Schora, F. C., P. B. Tarman, and H. L. Feldkirchner. In Situ Shale Processing. Hydrocarbon Processing, v. 56, No. 3, March 1977, pp. 127-128.

18. State-of-the-Art - Above Ground Shale Processing. Hydrocarbon Processing, v. 56, No. 2, February 1977, pp. 113-119

19. Schora, F. C., P. B. Tarman, H. L. Feldkirchner, and S. A. Weil. Process Shale SNG. Hydrocarbón Processing, v. 56, No. 4, April 1977, pp. 107-110. 
20. Smith, H. M. Correlation Index to Aid in Interpreting Crude Oil Analysis. BuMines, Technical Paper 610, 1941, 34 pp.

21. Sturm, G. P., Jr., P. W. Woodward, J. W. Vogh, S. A. Holmes, and J. E. Dooley. Analyzing Heavy Ends of Crude: Bartlett Oil. BERC/RI-77/7, May 1977, 24 pp.

22. Analyzing Syncrude from Western Kentucky Coal. B́ERC/RI-75/12, November 1975, 27 pp.

23. Thompson, C. J., J. E. Dooley, D. E. Hirsch, and C. C. Ward. Analyzing Heavy Ends of Crude (Gach Saran, Iran), Hydrocarbon Processing, v. 52, No. 9, September 1973, pp. 123-130.

24. Woodward, P. W., G. P. Sturm, Jr., J. W. Vogh, S. A. Holmes, and J. E. Dooley. Compositional Analysis of Synthoil from West Virginia Coal. BERC/RI-76/2, January 1976, 22 pp. 